\title{
Application of Nitrogen and Oxygen Isotopes for Source and Fate Identification of Nitrate Pollution in Surface Water: A Review
}

\author{
Yan Zhang ${ }^{1, *}$, Peng Shi ${ }^{2}$, Jinxi Song ${ }^{1, *}$ and Qi Li ${ }^{1}$ \\ 1 Shaanxi Key Laboratory of Earth Surface System and Environmental Carrying Capacity, College of Urban \\ and Environmental Sciences, Northwest University, Xi'an 710127, China; qili726@nwu.edu.cn \\ 2 State Key Laboratory of Eco-hydraulics in Northwest Arid Region of China, Xi'an University of Technology, \\ Xi'an 710048, China; shipeng015@163.com \\ * Correspondence: yanz@nwu.edu.cn (Y.Z.); jinxisong@nwu.edu.cn (J.S.); Tel.: +86-29-8830-8421 (Y.Z.)
}

Received: 10 November 2018; Accepted: 14 December 2018; Published: 21 December 2018

\begin{abstract}
Nitrate pollution in surface water has become an environmental problem of global concern. The effective way for controlling the nitrate pollution of surface water is to identify the pollution source and reduce the input of nitrate. In recent decades, nitrogen $\left(\delta^{15} \mathrm{~N}\right)$ and oxygen $\left(\delta^{18} \mathrm{O}\right)$ isotopes of nitrate has been used as an effective approach for identifying the source and fate of nitrate pollution in surface water. However, owing to the complexity of nitrate pollution source and the influence of isotopic fractionation, the application of this method has some limitations. In this work, we systematically discussed the fundamental principle of using nitrogen and oxygen isotopes to trace the nitrate source, the fate identification of nitrate, and the major testing techniques. Subsequently, the applications of nitrogen and oxygen isotopes for source identification of surface water were illustrated. However, there are still significant gaps in the application of the source identification and transformation mechanisms to nitrate and many research questions on these topics need to be addressed.
\end{abstract}

Keywords: nitrate pollution; surface water; source identification; isotope; contribution ratio

\section{Introduction}

Growing nitrate pollution has become a common environmental problem worldwide [1]. Rivers are important channels which connect the nitrogen pools of mainland and ocean. The ever-increasing nutrient substances in rivers are the key changing factors of the global water quality and biodiversity. The data from the Global Environmental Monitoring System shows that the nitrate concentrations are seven times as high as the allowable maximum pollutant concentration $(45 \mathrm{mg} / \mathrm{L})$ in most rivers [2,3]. The excessive amount of nitrate in surface water not only results in the eutrophication of water body but also poses a direct threat to human health [4]. Therefore, it is of significance to identify the sources of nitrate, and analyze the nitrate transformation mechanism for water environmental protection.

The nitrate sources of surface water are diversified and mainly include precipitation, mineralization of soil nitrogen, farmland fertilization, septic tank emissions, manure, domestic wastewater, and industrial sewage [5]. The human activity, hydrologic process, and migration and transformation mechanisms of nitrate vary within different land uses [6]. The major source of nitrate pollution is generally determined by the geographic position, scale, land-use type, and hydrological conditions of the watershed. Because the nitrogen isotopic compositions of nitrate and the fractionation mechanisms of nitrogenous substances are different, the value of $\delta^{15} \mathrm{~N}$ has been used to identify nitrate 
sources since the 1970s [7]. The continuous progress of source tracing technology has gone through four stages, i.e., source apportionment using $\delta^{15} \mathrm{~N}$, source apportionment using $\delta^{15} \mathrm{~N}$ and $\delta^{18} \mathrm{O}$, source apportionment using multi-isotopes, and research of mathematical models. However, a global database of $\delta^{15} \mathrm{~N}$ and $\delta^{18} \mathrm{O}$ is lacking in previous researches. The comprehensive analysis on the transformation mechanism of nitrogen is also not clear. Moreover, the degree of isotopic fractionation is difficult to quantify. Until now, there is no review that systematically summarizes present limitations and future prospects of application of nitrogen and oxygen isotopes. Thus, the present work analyzed the composition characteristics of $\delta^{15} \mathrm{~N}$ and $\delta^{18} \mathrm{O}$ values of various sources and the influencing factors. The application cases of stable isotope technique under different land-use types and basin conditions were also summarized. This review would provide a theoretical basis for the control of nitrate pollution in surface water.

\section{Fundamental Principle of Using Nitrogen and Oxygen Stable Isotopes to Identify the Pollution Source and Fate of Nitrate of Surface Water}

\subsection{Compositions of Nitrogen and Oxygen Stable Isotopes}

There are two naturally occurring stable isotopes of nitrogen, namely, ${ }^{14} \mathrm{~N}$ and ${ }^{15} \mathrm{~N}$, and the corresponding natural abundances are $99.633 \%$ and $0.366 \%$, respectively. Oxygen is composed of three stable isotopes, ${ }^{16} \mathrm{O}(99.757 \%),{ }^{17} \mathrm{O}(0.038 \%)$, and ${ }^{18} \mathrm{O}(0.205 \%)$. Nitrogen and oxygen participate in various physical processes and chemical reactions in the natural environment. The stable isotope composition is usually expressed in delta $(\delta)$ units and a per mil $(\%)$ notation relative to the respective international standards

$$
\delta=\left(R_{\text {sample }} / R_{\text {standard }}-1\right) \times 1000,
$$

where the positive value and negative value of $\delta$ respectively represent the enrichment and impoverishment of heavy isotopes in test sample compared with a standard sample. The nitrogen and oxygen isotopic ratios $(R)$ are reported as the per mil deviation from the ${ }^{15} \mathrm{~N} /{ }^{14} \mathrm{~N}$ or ${ }^{18} \mathrm{O} /{ }^{16} \mathrm{O}$ ratios relative to $\mathrm{N}_{2}$ (air) and Vienna Standard Mean Ocean Water (V-SMOW). The overall error of measurement is below $1 \%$.

The $\delta^{15} \mathrm{~N}$ and $\delta^{18} \mathrm{O}$ compositions of nitrate differ in different potential sources. $\delta^{15} \mathrm{~N}$ is light in precipitation $\left(\delta^{15} \mathrm{~N}\right.$ value ranges from $-10 \%$ to $8 \%$ ) and chemical fertilizer $\left(\delta^{15} \mathrm{~N}\right.$ value ranges from $0 \%$ to $3 \%$ ). After the nitrification of microorganisms, the $\delta^{15} \mathrm{~N}$ value of soil nitrogen ranges from $-3 \%$ to $5 \%$. However, $\delta^{15} \mathrm{~N}$ is heavy in manure and sewage $\left(\delta^{15} \mathrm{~N}\right.$ value ranges from $7 \%$ to $20 \%$ o or is larger than $20 \%$ ) $[5,8] . \delta^{15} \mathrm{~N}$ plays an important role in identifying the nitrate from ammonium nitrogen fertilizer, soil nitrogen, manure, and sewage. The $\delta^{15} \mathrm{~N}$ values of nitrate from precipitation, soil, chemical fertilizer, manure, and sewage partly overlap (Figure 1). The synthetic fertilizer or ammonia fertilizer do not contribute to the increase of $\delta^{15} \mathrm{~N}$ as they are both from atmospheric $\mathrm{N}_{2}$ [9], so the $\delta^{15} \mathrm{~N}$ of precipitation is not significantly different from that of synthetic fertilizer. The application of $\delta^{15} \mathrm{~N}$ is not enough for the accurate identify of nitrate source. Mostly, it is combined with $\delta^{18} \mathrm{O}$, another indicator for identifying nitrate source, so as to reduce the uncertainties of nitrogen isotope in identification [10]. The $\delta^{18} \mathrm{O}$ value of precipitation is high and usually ranges between $+20 \%$ and $+70 \%$. The $\delta^{18} \mathrm{O}$ value of synthetic nitrate nitrogen fertilizer is $22 \% 0 \pm 3 \%$, while the $\delta^{18} \mathrm{O}$ value of soil nitrogen transformed from in-situ ammonium nitrogen by nitrification is between $-5 \%$ and $5 \%$. The final production of $\delta^{18} \mathrm{O}$ varies with the nitrification ways as well as the $\delta^{18} \mathrm{O}$ ratio of $\delta^{18} \mathrm{O}-\mathrm{O}_{2}$ in atmosphere to $\delta^{18} \mathrm{O}-\mathrm{H}_{2} \mathrm{O}$ in water. The values of $\delta^{18} \mathrm{O}$ in manure and sewage are lower than $15 \%$ [11].

The major sources of nitrate are preliminarily determined by comparing dual stable isotopes $\left(\delta^{15} \mathrm{~N}\right.$ and $\left.\delta^{18} \mathrm{O}\right)$ of potential sources with those of surface water. Due to the influence of regional climate, source emissions, topography, geology, etc., the isotopic compositions from different nitrogen sources vary widely in different regions and time [12,13]. For example, the typical range of $\delta^{15} \mathrm{~N}$ in the precipitation is from $-3 \%$ to $7 \%$ in China [14-16], while that is from $-6 \%$ to $11 \%$ in other countries and regions $[11,17]$. The typical value range of $\delta^{15} \mathrm{~N}$ of soil organic nitrogen is from $3 \%$ to 
$8 \%$ [18,19], while that is reported to be from 0 to $8 \%$ in other countries and regions [11]. The typical value range of $\delta^{15} \mathrm{~N}$ of Chinese chemical fertilizer is between $-6 \%$ and $5 \%$ [4], which is smaller than that of American fertilizer (between $-4 \%$ and $8 \%$ ) [20]. The current studies on isotope composition are limited to scattered regions. The lack of a global landscape map of nitrogen and oxygen stable isotopes of nitrate in surface water has greatly affected the accuracy of the results of the application of nitrogen and oxygen isotopes. The global and regional stable isotope databases should be established to quickly and accurately identify the source of nitrate pollution.

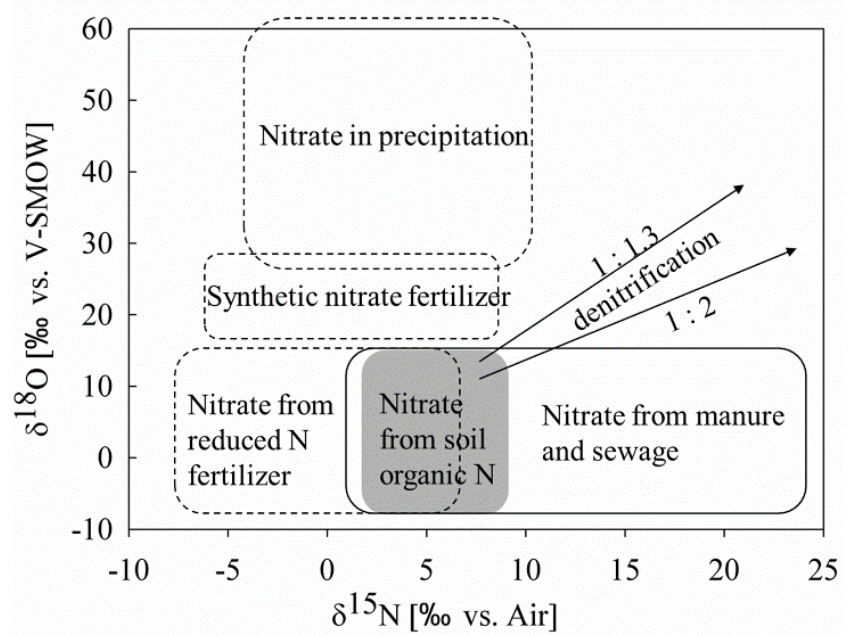

Figure 1. Distribution of $\delta^{15} \mathrm{~N}$ and $\delta^{18} \mathrm{O}$ from different potential nitrate sources.

\subsection{Isotopic Fractionation}

The nitrogen and oxygen isotopes have been widely used in the effective identification of nitrate pollution sources of surface water. Nevertheless, during the nitrogen cycle, complex isotopic fractionation altered $\delta^{15} \mathrm{~N}$ and $\delta^{18} \mathrm{O}$ compositions, thereby leading to the incorrect identification of nitrate source. The reaction processes which affect the isotopic composition include nitrification, denitrification, volatilization, assimilation, and mineralization [21,22].

Nitrification refers to the process in which ammonium salt is oxidized to nitrate by nitrobacteria. Because the microorganisms give priority to utilize light isotopes $\left({ }^{14} \mathrm{~N}\right.$ and $\left.{ }^{16} \mathrm{O}\right)$, lots of $\delta^{15} \mathrm{~N}$ and $\delta^{18} \mathrm{O}$ are enriched in the nitrate. One-third of the oxygen of the newly generated nitrate should be derived from the dissolved oxygen in atmosphere and the other two-thirds are from the surrounding water bodies [4]. No isotopic fractionation occurs during the oxygen combination. The $\delta^{18} \mathrm{O}$ generated through nitrification process can be calculated by Equation (2) with the known $\delta^{18} \mathrm{O}-\mathrm{O}_{2}$ in atmosphere and $\delta^{18} \mathrm{O}-\mathrm{H}_{2} \mathrm{O}$ in water, and the $\delta^{18} \mathrm{O}$ usually ranges from $-10 \%$ to $+10 \%$. The $\delta^{18} \mathrm{O}$ value of nitrate in the water samples collected from agricultural area are within this range. In rivers run in forest area, the $\delta^{18} \mathrm{O}$ value is relatively high and is above $+16 \%$ [11,12]. If the measured $\delta^{18} \mathrm{O}$ value is within the calculated range of $\delta^{18} \mathrm{O}$, it indicates that nitrate is greatly influenced by nitrification. If the measured value of $\delta^{18} \mathrm{O}$ is not within the calculated range, one possibility is that the isotopic compositions are slightly influenced by nitrification [18]. Another possibility is that the evaporation of soil water and the respiration of oxygen in atmosphere have led to the rise of $\delta^{18} \mathrm{O}$ value, that is, the measured value of $\delta^{18} \mathrm{O}$ is higher than the calculated one [23]. High temperature will facilitate the respiration of microorganisms, especially in summer, resulting in the enrichment of $\delta^{18} \mathrm{O}-\mathrm{O}_{2}$.

$$
\delta^{18} \mathrm{O}=2 / 3 \delta^{18} \mathrm{O}-\mathrm{H}_{2} \mathrm{O}+1 / 3 \delta^{18} \mathrm{O}-\mathrm{O}_{2}
$$

Denitrification occurs under anaerobic conditions or low concentration of dissolved oxygen $(<2 \mathrm{mg} / \mathrm{L})$ [24]. During denitrification, ${ }^{14} \mathrm{~N}$ and ${ }^{16} \mathrm{O}$ are respectively converted to $\mathrm{N}_{2} \mathrm{O}$ and $\mathrm{N}_{2}$ by microorganisms, resulting in an enrichment of ${ }^{15} \mathrm{~N}$ and ${ }^{18} \mathrm{O}$ in the remaining nitrate. The enrichment 
factors range from $-40 \%$ to $-5 \%$ for nitrogen isotope [25] and from $-18 \%$ o to $-8 \%$ for oxygen isotope [26]. The extent of fractionation resulted from denitrification is influenced by the surrounding circumstances. Besides, denitrification will lead to a negative correlation between $\delta^{15} \mathrm{~N}$ value and nitrate concentration. According to the Rayleigh equation, the logarithmic values of nitrate should be linearly correlated with $\delta^{15} \mathrm{~N}$ and $\delta^{18} \mathrm{O}$ values, respectively. If $\delta^{15} \mathrm{~N}$ displays a significant negative linear correlation with $\delta^{18} \mathrm{O}$, the denitrification is responsible for nitrate transformation [18]. Denitrification will lead to the decreased nitrate concentration but increased values of $\delta^{15} \mathrm{~N}$ and $\delta^{18} \mathrm{O} \cdot \delta^{15} \mathrm{~N}$ and $\delta^{18} \mathrm{O}$ are correlated positively by a factor between 1.3:1 and 2.1:1 $[4,27,28]$. Denitrification has a great enrichment effect on $\delta^{15} \mathrm{~N}$, while $\delta^{18} \mathrm{O}$ is rarely affected by denitrification. It indicates that denitrification process is accompanied by some other reactions concerning nitrate [29].

The volatilization of ammonia will lead to the enrichment of $\delta^{15} \mathrm{~N}_{-} \mathrm{NH}_{4}{ }^{+}$in the remaining ammonium salt, followed by nitrification that may result in the formation of which will further nitrate with enriched $\delta^{15} \mathrm{~N}$ [30]. The assimilation process, in which plants utilize ammonium salt, nitrate, and nitrite, will result in extensive isotopic fractionation (usually ranges from $-27 \%$ to $0 \%$ ). Theoretically, the fractionation ratio of $\delta^{15} \mathrm{~N}$ to $\delta^{18} \mathrm{O}$ caused by assimilation is 1:1 [31]. Biological nitrogen fixation is a major source of nitrogen of surface water. During biological nitrogen fixation process, the molecular nitrogen is converted to ammonia. The $\delta^{15} \mathrm{~N}$ value of the nitrogenous substances generated by nitrogen fixation is close to that of atmospheric $N_{2}(0 \%)$ [32]. However, the organic substances produced by diazotrophs will undergo mineralization or nitrification, which eventually indirectly affect the concentration and $\delta^{15} \mathrm{~N}$ value of nitrate.

The above-mentioned biochemical processes are easily affected by land-use types, climate, hydrological conditions, and migration pathways. It is important to quantify the influence of these factors on the identification of pollution sources and transformation of tracer nitrogen. The fractionation produced by denitrification is relatively high, while the nitrogen isotopic fractionation is relatively low during nitrification, ammonia volatilization, mineralization, assimilation, and nitrogen fixation. Approximately $72 \%$ of the nitrogen entering the river is removed during processes like biological absorption, atmospheric deposition, leakage to the bottom aquifer, and microbial denitrification [33,34]. Denitrification is the only way to permanently remove nitrogen in the rivers, and it can directly and significantly change the isotope values of nitrates. The denitrification determination and the attenuation mechanism of nitrate are applicable to specific geological and hydrological conditions. The mechanisms of isotopic fractionation would be influenced by land use, vegetation, soils, industry, agriculture, mixed-degree of different sources, and complex transformation processes of the nitrogen cycle. The current researches of isotopic fractionation are limited to qualitative level and they lack a quantitative basis. That is, they can only determine whether isotopic fractionation has occurred, but they cannot analyze the degree of fractionation caused by various biochemical reactions. Therefore, the mechanisms of the related process are still unclear.

\section{Research Progress in Analytical Techniques of Nitrogen and Oxygen Isotopes}

It has been proven that nitrogen and oxygen isotopes have been used as effective approaches for identifying the source and fate of nitrate pollution in surface water. Thus, it is crucial to ensure that the testing technique of isotopic compositions is accurate, rapid, and inexpensive. Ion-exchange method, denitrifier method, and Cd-azide reduction method are the most common approaches currently used for analytical techniques for $\delta^{15} \mathrm{~N}$ and $\delta^{18} \mathrm{O}$ determination.

Ion exchange method was developed by Silva et al. [35]. This method has three steps, i.e., transformation, purify, and mass spectroscopy analysis. Briefly, nitrate is purified and concentrated by passing samples through ion exchange resin columns, and then can be simultaneously analyzed $\delta^{15} \mathrm{~N}$ and $\delta^{18} \mathrm{O}$ values via isotope ratio mass spectrometer (IRMS). The adsorption rate and elution rate during the transformation are two key indicators for experimental operation. Incorrect operation will cause nitrogen isotopic fractionation, which results in smaller measured values. Garten [36] found that the absorption rate of anion exchange resin (Rowex 1-X8) was more than $97 \%$, and the recovery 
of saturated $\mathrm{K}_{2} \mathrm{SO}_{4}$ solution was close to $100 \%$. No obvious isotopic fractionation occurred during the adsorption and desorption of zwitterion, and the deviation was below $0.3 \%$. In traditional mass spectroscopy, prepared $\mathrm{AgNO}_{3}$ samples are put into sealed tube for high temperature combustion so that the $\mathrm{AgNO}_{3}$ are converted into $\mathrm{N}_{2}$ and $\mathrm{CO}_{2}$ and then values of $\delta^{15} \mathrm{~N}$ and $\delta^{18} \mathrm{O}$ can be measured through IRMS. Mass spectroscopy is not widely used because it is cumbersome in preprocessing steps and needs lots of $\mathrm{AgNO}_{3}$ samples. Recently, a new testing technique of higher accuracy has gotten extensive applications. In this method, prepared $\mathrm{AgNO}_{3}$ samples are placed in aluminum or silver tube at $1400{ }^{\circ} \mathrm{C}$ in an element analyzer, samples can be conducted by conversion to $\mathrm{N}_{2}$ and CO. Subsequently, the isotope values are measured through IRMS. This method has the following demerits: (1) the amount of require water sample is huge, and a relatively large amount of $\mathrm{N}$ in samples $(>1 \mu \mathrm{mol} N)$ is essential to avoid contamination from atmospheric $\mathrm{N}_{2}$ [37]; (2) chemical reagents (e.g., silver oxide) used for sample preparation are very expensive; (3) influence of other ions (e.g., $\mathrm{SO}_{4}{ }^{2-}$ and $\mathrm{Cl}^{-}$) on the quantification of nitrate concentration [38]. The merits of this method can be summarized as follows: (1) it achieves a high level of sensitivity and is easy to operate [12]; (2) no harmful preservatives are added into sample water and thus cross contamination can be effectively avoided; (3) the preservation time is long (two years when refrigerated in humid environment); (4) isotopic fractionation only occurs to a small extent. This method is a well-developed approach for the measurement of $\delta^{15} \mathrm{~N}$ and $\delta^{18} \mathrm{O}$, and has been widely used in field experiments.

Denitrifier method was put forward by Sigman et al. [39] and Caaciotti et al. [40]. In this method, the simultaneous determination of $\delta^{15} \mathrm{~N}$ and $\delta^{18} \mathrm{O}$ of $\mathrm{N}_{2} \mathrm{O}$ produced from the conversion of nitrate by denitrifying bacteria which naturally lack $\mathrm{N}_{2} \mathrm{O}$-reductase activity. This method has four experimental steps, namely, bacterial selection, bacterial cultivation, conversion, and extraction of $\mathrm{N}_{2} \mathrm{O}$. This method has many advantages. First of all, it only requires a small amount of sample water and is able to be used for the analysis of low-concentration samples. Apart from that, it only converts nitrate and is completely uninfluenced by organic nitrogen. Besides, it shortens the analyzing time because the preparation procedure is simple. Moreover, it is also applicable for samples with a concentration of nitrate lower than $1 \mathrm{M}$. The denitrifier method has been used as a standard technique by the United States Geological Survey to determine the $\delta^{15} \mathrm{~N}$ and $\delta^{18} \mathrm{O}$ of nitrate [41]. The nitrogen is completely transformed during the denitrification, so $\delta^{15} \mathrm{~N}$ only needs a blank correction. However, the oxygen in nitrate is not completely transformed into $\mathrm{N}_{2} \mathrm{O}$ and there is oxygen isotopic fractionation, so $\delta^{18} \mathrm{O}$ needs correction of oxygen isotopic fractionation, exchange, and blank. The limitation of this method lies in that it fails to distinguish the nitrate in water sample from nitrite, and thus the presence of nitrite in water samples can bias the isotopic composition of product $\mathrm{N}_{2} \mathrm{O}$. For this reason, if the water sample contains nitrite, the nitrite should be removed first [42]; otherwise, the measured results should be corrected [43]. In addition, it needs a long time to cultivate bacteria, in which the bacteria are likely to be affected by toxicity of the sample. Therefore, the rapid and complete transformation of nitrate into $\mathrm{N}_{2} \mathrm{O}$ should be considered in the selection and culture of bacteria. Zhu et al. [44] modified the classical denitrifier method with $P$. aureofaciens for robust and reliable conversion of nitrate to $\mathrm{N}_{2} \mathrm{O}$ without prior induction of denitrification with extraneous nitrate.

Cd-azide reduction method, proposed by McIlivin et al. [45], is a new method which is able to measure $\delta^{15} \mathrm{~N}$ and $\delta^{18} \mathrm{O}$. In this method, $\mathrm{Cd}$ is added into water sample to reduce nitrate into nitrite and then azides are added as well so that the nitrite can be further reduced into $\mathrm{N}_{2} \mathrm{O}$. Subsequently, high-purity $\mathrm{N}_{2} \mathrm{O}$ can be obtained through separation, enrichment, and purification. Finally, the compositions of $\delta^{15} \mathrm{~N}$ and $\delta^{18} \mathrm{O}$ are measured through IRMS. Apart from not being susceptible to organic substances, advantages of this method also include simple preparation procedure, inexpensive, small sample volumes, and automation with high sample throughput. However, this method is dangerous due to the toxicity of the adopted reagents [46]. Furthermore, the nitrite in water sample will lead to the deviation of $\delta^{15} \mathrm{~N}$ and $\delta^{18} \mathrm{O}$ values, so the measured results need further correction. 
Even though the accuracies of the above mentioned three simultaneous testing techniques for $\delta^{15} \mathrm{~N}$ and $\delta^{18} \mathrm{O}$ have been significantly improved, they still have certain limitations in tracing nitrate pollution sources of surface water. The preparation procedure of water samples will directly affect the accuracy of final results. So far, no single simple method has been able to automatically extract the nitrate in water samples and meanwhile to completely avoid the isotope contamination and fractionation.

\section{Application of Nitrogen and Oxygen Isotopes in Nitrate Source Tracing of Surface Water under Different Land-Use Types}

Chemical fertilizer, manure, precipitation, soil nitrogen, and nitrogen fixation are the main sources of nitrate in rivers which run in the basin mostly covered with agricultural land. The crop species cultivated in farmland, the fertilizing methods, and the activities of microorganisms in soil vary in different seasons, so these factors have great influences on the source identification of nitrate in surface water within farmland area. The nitrate in farmland soil which comes from different sources is transferred to surface water through processes like eluviation [5]. Kellan et al. [22] found that the $\delta^{15} \mathrm{~N}$ value in the wastewater of farmland applied with pig manure was much higher than that in the wastewater of farmland applied with inorganic fertilizer. It was also higher than that of pig manure. This evidence indicates that the $\delta^{15} \mathrm{~N}$ in farmland soil has been fractionated and inorganic fertilizer and animal manure are the major sources of the nitrate in farmland wastewater. When the nitrate derived from atmospheric precipitation, fertilizer, or soil transfers from soil system to rivers, influencing factors like microorganisms may cause the enrichment of ${ }^{15} \mathrm{~N}$. Consequently, the isotopic characteristics of nitrate source disappear. However, in the event that the activity of microorganisms is low, $\delta^{15} \mathrm{~N}$ and $\delta^{18} \mathrm{O}$ values are relatively stable during nitrate transfer, in which case the nitrate source can be correctly identified [5,47]. Deutsch et al. [47] reported that $\delta^{15} \mathrm{~N}$ and value of farmland wastewater in winter was significantly higher than those of groundwater and precipitation, but the $\delta^{18} \mathrm{O}$ value of farmland wastewater was much higher than that of groundwater yet was far lower than that of precipitation. The $\delta^{15} \mathrm{~N}$ and $\delta^{18} \mathrm{O}$ values of rivers and farmland wastewater were close. The results of researches conducted on nitrogen and oxygen isotopes technique and geochemical methods show that the high-concentration of nitrate in farmland wastewater and in rivers is directly correlated with the use of massive chemical fertilizers $[4,48]$. Besides, it has been proven that the negative impacts of fertilizer can be largely reduced by proper agricultural management [49].

Precipitation and soil are the major sources of the nitrate in rivers which run in the basin mostly covered with forestland. Nitrate from soil includes the soil organic nitrogen and the nitrate transformed from the $\mathrm{NH}_{4}{ }^{+}$in soil through nitrification. Though the $\delta^{15} \mathrm{~N}$ values of these sources are quite close, the enrichment of $\delta^{18} \mathrm{O}$ in atmospheric precipitation makes it possible to correctly identify the nitrate source through $\delta^{18} \mathrm{O}$ value [4]. When the precipitation is low in amount, the nitrification in soil is the main reason for the increase of the nitrate concentration of rivers within forestland-covered basin [50,51]. The nitrogen in precipitation is unable to go into rivers directly for being intercepted by forestland, and thus the nitrogen is absorbed by organisms where organic nitrogen is synthesized. The nitrate will be produced by the mineralization and nitrification of upper soil organic nitrogen. The nitrate in soil will eventually enter surface rivers under eluviation, infiltration, etc. [52]. After analyzing the $\delta^{15} \mathrm{~N}$ and $\delta^{18} \mathrm{O}$ composition of surface water within the forestland-covered basin in Northeastern United States, Burns et al. [28] found that over $80 \%$ of nitrate was generated by the nitrification of soil nitrogen. When the precipitation increased, the soil organic nitrogen and precipitation became the major contributors of nitrate in rivers within forestland-covered basin [53]. Besides, the data of $\delta^{18} \mathrm{O}$ show that the atmospheric nitrate will go into rivers after the nitrification of microorganisms [51].

As for the basin mostly covered with urban mixed-use land, the nitrate of surface water is mainly from domestic wastewater, industrial sewage, chemical fertilizer, manure, soil nitrogen, and atmospheric precipitation. Seasonal changes and human activities are the major influencing factors altering nitrate sources of surface water within this kind of basin. There are lots of impervious 
surfaces which only intercept a small amount of precipitation and thus most of the precipitation will go into surface rivers. Therefore, seasonal change of precipitation has a great impact on the nitrate in urban rivers. During rainy season, the contribute rate of atmospheric precipitation to nitrate in surface rivers can reach $50 \%$ or even $67 \%$ [28,53]. By measuring $\delta^{15} \mathrm{~N}$ and $\delta^{18} \mathrm{O}$ values, Chen et al. [54] studied the sources of nitrate in Taihu Lake area. The nitrate mainly derived from precipitation, domestic wastewater, and organic fertilizer in summer, while it was from the nitrification of domestic wastewater, organic fertilizer and soil organic nitrogen in winter. The source of nitrate in surface water varies both in seasons and spatial distribution. Lee et al. [55] reported that precipitation and soil organic substance were the major sources of the nitrate in the northern part of Han River, but manure and sewage were the main sources in the southern part of Han River. With $\delta^{15} \mathrm{~N}$ and $\delta^{18} \mathrm{O}$ isotopes, Ren et al. [56] studied the surface water within the urban area of Beijing and found that the main sources of nitrate were manure and sewage. After investigating the pollution source of the nitrogen compound along the Olt River, Popescu et al. [57] found that inorganic nitrogen pollution was mainly caused by agricultural and domestic wastewater. Based on $\delta^{15} \mathrm{~N}$ and $\delta^{18} \mathrm{O}$, Archana et al. [58] found that sewage was the main nitrate source of surface water, and assimilation, nitrification, and nitrogen fixation were the major driving factors under the complicated urban circumstances.

The $\delta^{15} \mathrm{~N}$ and $\delta^{18} \mathrm{O}$ has been widely applied in the source identification of nitrate in surface water within the above-mentioned small-scale basins and within other large-scale basins. Table 1 presents the data of the source identification of nitrate in surface water in large-scale basins all over the world. As suggested by the data, stable isotope method has provided useful information for analyzing the source and fate of nitrate as well as for the removal of nitrate. The nitrate source of surface water varies according to time and space. Besides, the nitrogen sources will go through several biochemical reactions (ammonization, nitrification, and denitrification) before entering rivers. However, these biochemical reactions are easy to be affected by land-use types, climate, hydrological conditions, and migration ways. At present, most of the researches only analyzed nitrate sources by comparing the $\delta^{15} \mathrm{~N}$ and $\delta^{18} \mathrm{O}$ values of surface water with the $\delta^{15} \mathrm{~N}$ and $\delta^{18} \mathrm{O}$ values from different sources. They ignored the influence of nitrogen sources on isotopic fractionation during migration and transformation, and failed to calculate the effect extent of fractionation on the results. Because of the complexity of the river system, simple isotopic geochemistry research is not enough to reveal the geochemical cycle process of river nitrate. Thus, it is of great significance to study the extent of these influences for identifying the nitrate pollution sources for tracing the migration and transformation ways of nitrogen. Furthermore, other indicators like hydrological conditions, water quality, and land-use types are necessary if detailed analyses on the source of nitrate in large-scale basin and on the pollution characteristics are to be conducted.

Table 1. Application of nitrogen and oxygen isotopes for the identification of nitrate source and fate in surface water in large-scale basins.

\begin{tabular}{cccc}
\hline Watersheds & Area $\left.\mathbf{( k m}^{\mathbf{2}}\right)$ & Main Sources & References \\
\hline $\begin{array}{c}\text { Mississippi River Basin, } \\
\text { United States }\end{array}$ & $2.9 \times 10^{6}$ & Stream nitrogen assimilation & [59] \\
\hline $\begin{array}{c}\text { Changjiang River Basin, } \\
\text { China }\end{array}$ & $1.8 \times 10^{6}$ & $\begin{array}{c}\text { Nitrification (including "modified fertilizer") and } \\
\text { urban sewage effluent }\end{array}$ & [19] \\
\hline $\begin{array}{c}\text { Yellow River Basin, } \\
\text { China }\end{array}$ & $7.5 \times 10^{5}$ & $\begin{array}{c}\text { Sewage/manure effluents in the upstream; } \\
\text { manure/sewage effluents and ammonium/urea- } \\
\text { containing fertilizer in the middle and lower reaches }\end{array}$ & [60] \\
\hline $\begin{array}{c}\text { Songhua River Basin, } \\
\text { China }\end{array}$ & $5.6 \times 10^{5}$ & $\begin{array}{c}\text { Soil organic nitrogen, nitrogenous fertilizers, and } \\
\text { sewage in the high flow season; soil organic nitrogen } \\
\text { and sewage in the low flow season. }\end{array}$ & [61] \\
\hline
\end{tabular}


Table 1. Cont.

\begin{tabular}{|c|c|c|c|}
\hline Watersheds & Area $\left(\mathrm{km}^{2}\right)$ & Main Sources & References \\
\hline $\begin{array}{l}\text { Illinois River Basin, } \\
\text { United States }\end{array}$ & $7.8 \times 10^{4}$ & $\begin{array}{l}\text { A mixture of relatively undenitrified tile drain } \\
\text { waters, highly denitrified groundwater, and } \\
\text { treated wastewater }\end{array}$ & [62] \\
\hline $\begin{array}{l}\text { Oldman River basin, } \\
\text { Canada }\end{array}$ & $3.0 \times 10^{4}$ & $\begin{array}{l}\text { Soil nitrification in the western tributaries; manure } \\
\text { and/or sewage in the eastern tributaries }\end{array}$ & [63] \\
\hline Lake Winnipeg, Canada & $2.45 \times 10^{4}$ & $\begin{array}{c}\text { Manure and/or wastewater discharge and inorganic } \\
\text { agricultural fertilizers }\end{array}$ & [64] \\
\hline $\begin{array}{l}\text { Guadalhorce River Basin, } \\
\text { Spain }\end{array}$ & $3.2 \times 10^{3}$ & Fertilizers and organic sources (manure and sewage) & [65] \\
\hline Taihu Lake, China & $2.3 \times 10^{3}$ & $\begin{array}{l}\text { Sewage/manure, and soil organic } \mathrm{N} \text { in winter; } \\
\text { atmospheric precipitation and sewage/manure } \\
\text { inputs in summer }\end{array}$ & [54] \\
\hline
\end{tabular}

\section{Source Identification of Nitrate in Surface Water by Nitrogen and Oxygen Isotope-Based Methods}

The conventional methods based on land-use types, hydrochemistry, multiple isotopes $\left(\delta^{2} \mathrm{H}, \delta^{18} \mathrm{O}\right.$, $\delta^{11} \mathrm{~B}, \delta^{13} \mathrm{C}$, and $\delta^{34} \mathrm{~S}$ ) and dual isotopes of nitrate are combined to reduced isotopic fractionation caused by objective factors like spatial-temporal change [5,12,57]. Xing et al. [18] carried out a study on the rivers on the Loess Plateau and found that nitrate was the major existing form of nitrogen in these rivers. Land-use type has an obvious impact on nitrogen concentration. The nitrate concentrations of rivers affected by coal are an order of magnitude higher than those of samples collected in forest or agricultural areas. As the original values of $\delta^{15} \mathrm{~N}$ and $\delta^{18} \mathrm{O}$ differ according to the land-use types, correlation analysis should be conducted on them under each land-use type. The solute tracers in hydrochemistry like soluble ions $\left(\mathrm{Cl}^{-}\right.$and $\left.\mathrm{Br}^{-}\right)$link with the ratio difference between different ions (content ratios of $\mathrm{NO}_{3}{ }^{-} / \mathrm{Cl}^{-}, \mathrm{Cl}^{-} / \mathrm{Br}^{-}, \mathrm{Cl}^{-} / \mathrm{Na}^{+}$, and $\mathrm{SO}_{4}{ }^{2-} / \mathrm{Ca}^{2+}$ ) are conductive to the accurate nitrate source identification based on $\delta^{15} \mathrm{~N}$ and $\delta^{18} \mathrm{O}[4,12,66] . \mathrm{Cl}^{-}$is difficult to have physical, chemical, or biological reactions and thus is a good indicator for reflecting the input and dilution of domestic sewage. Chen et al. [67] reported that whether the nitrate of surface water was mainly from fertilizer or animal manure and sewage could be known by analyzing the molar ratio of $\mathrm{NO}_{3}{ }^{-} / \mathrm{Cl}^{-}$. Mayer et al. [68] found the reason for the increased $\delta^{15} \mathrm{~N}$ in water by analyzing the correlation between nitrate concentrations and $\delta^{15} \mathrm{~N}$ values. That is, the nitrification of microorganisms decreases nitrate concentration but increases $\delta^{15} \mathrm{~N}$. If they both increase, it may be because there are two or several nitrate sources with high in nitrate concentrations and $\delta^{15} \mathrm{~N}$ values. Showers et al. [69] attempted to identify the sources of nitrate in water samples collected from a farm. They found that there was little difference between $\delta^{15} \mathrm{~N}$ and $\delta^{18} \mathrm{O}$ of nitrate from the two possible sources, i.e., septic tanks and manure. Yet septic tanks could be excluded according to the difference between the compositions of $\delta^{2} \mathrm{H}$ and $\delta^{18} \mathrm{O}-\mathrm{H}_{2} \mathrm{O}$ of septic tank effluent and groundwater.

The change of isotope $\delta^{13} \mathrm{C}$ of dissolved inorganic carbon in river reflects the geochemical behaviors and biogeochemical cycle of carbon. The major sources of $\delta^{13} \mathrm{C}$ are decomposition of soil organic matters, dissolution of carbonate minerals, respiration of aquatic plants, and atmospheric $\mathrm{CO}_{2}$. As the carbon pools are quite different, the $\delta^{13} \mathrm{C}$ in water can provide important information for the evolution, biogeochemical cycle, and environmental change of carbon [70]. As the multi-sources of pollutant and reaction mechanism can cause the superposition of isotopic signals, the source of nitrate and its transformation ways can be traced through $\delta^{15} \mathrm{~N}, \delta^{18} \mathrm{O}$, and $\delta^{13} \mathrm{C}$. Li et al. [71] identified the source and transformation ways of nitrate in the upstream of Chaobai River, using the $\delta^{15} \mathrm{~N}$ and $\delta^{18} \mathrm{O}$ as well as $\delta^{13} \mathrm{C}$, and found that soil nitrogen was the major source of nitrate in rainy season, while sewage and manure were the major sources in dry season. Although denitrification did not occur, mineralization and nitrification played important roles in nitrogen biogeochemistry. 
Boron (B) isotope transports simultaneously with nitrate in surface water. Generally, B comes from fertilizer, manure, and household goods [23]. There is obvious difference in the compositions of $\delta^{11} \mathrm{~B}$ from different sources. Because $\mathrm{B}$ is not affected by transformation processes, the combined use of $\delta^{11} \mathrm{~B}$ and the dual isotopes of nitrate have great benefits of the correct identification of nitrate source. Xue et al. [66], by using $\delta^{15} \mathrm{~N}, \delta^{18} \mathrm{O}$ and $\delta^{11} \mathrm{~B}$, found that the major sources of the nitrate of surface water in the Flanders area of Belgium were manure and domestic sewage. Widory et al. [72] used $\delta^{11} \mathrm{~B}$ to evaluate the contribution of domestic sewage to nitrate. The $\delta^{11} \mathrm{~B}$ is an effective indicator for distinguishing animal waste (between $+6.9 \%$ and $+42.1 \%$ ) from domestic sewage (between $-7.7 \%$ o and $+12.9 \%$ ) .

${ }^{17} \mathrm{O}$ can be introduced into identifying nitrate source. Unlike $\delta^{18} \mathrm{O}$, the value of $\delta^{17} \mathrm{O}$ will not change during biochemical processes. Hence, $\delta^{17} \mathrm{O}$ is more sensitive and reliable in tracing the nitrate from atmospheric precipitation than the conventionally used $\delta^{18} \mathrm{O}$. The $\delta^{17} \mathrm{O}$ can be used to accurately recognize the nitrate from atmospheric precipitation $\left(\delta^{17} \mathrm{O}>0\right)$ and that from other pollution sources $\left(\delta^{17} \mathrm{O}=0\right)$ [73]. Tsunogai et al. [74] applied $\delta^{17} \mathrm{O}$ to quantify the rate of precipitation into lake. The total amount of nitrate in lake decreased during the observation period, indicating that nitrate from atmospheric precipitation was assimilated quickly in summer. More than $90 \%$ of the assimilated nitrate would be transformed into nitrate through mineralization during the nitrogen cycle. Scaccon et al. [75] — by using the $\delta^{15} \mathrm{~N}, \delta^{18} \mathrm{O}$, and $\delta^{17} \mathrm{O}$ of nitrate, the $\delta^{2} \mathrm{H}$ and $\delta^{18} \mathrm{O}-\mathrm{H}_{2} \mathrm{O}$; and the $\delta^{34} \mathrm{~S}$ and $\delta^{18} \mathrm{O}$ of sulfate- found that river pollution derived from agricultural activities, precipitation, nitrification, and urban sewage within Mariano lagoon basin in Italy.

In summary, the complex isotope fractionation during each process in the nitrogen cycle may change the $\delta^{15} \mathrm{~N}$ and $\delta^{18} \mathrm{O}$ values of nitrate pollution sources, which may lead to the deviation of nitrate pollution source identification. However, by combining with other isotopes or conventional methods, e.g., the solute tracer in hydrochemistry, the isotopes are still powerful to accurately analyze the nitrate pollution source and fate of surface water. In addition, some other methods-such as correlation analysis, end-member analysis [76], principal component analysis, classification-tree method [77], uncertainty analysis [78], and grey water footprint [79]—could be used to assist the source identification of nitrate pollution.

\section{Applications of Mathematical Models}

With the development of the techniques in tracing nitrate source, attempts have been made to establish quantitative mathematical models for analyzing the contribution ratios of different sources to the nitrate in surface water. They are believed to move the study on nitrate pollution source identification from qualitative to quantitative. The main mathematical models currently used are introduced in the following subsections.

\subsection{Mass-Balance Mixing Model}

Phillips et al. (2002) [80] developed an alternative mixing model based on two isotopes and three sources and incorporates concentration variation. The calculation formulas of this model are expressed as

$$
\begin{gathered}
\delta^{15} \mathrm{~N}=\sum_{i=1}^{3} f i \times \delta^{15} \mathrm{~N}_{i} \\
\delta^{18} \mathrm{O}=\sum_{i=1}^{3} f i \times \delta^{18} \mathrm{O}_{i}, \\
\sum_{i=1}^{3} f i=1,
\end{gathered}
$$

where $i$ represents the pollution source of nitrate, $\delta^{15} \mathrm{~N}$ represents the abundance of $\delta^{15} \mathrm{~N}$ of nitrate in mixed water sample, $\delta^{18} \mathrm{O}$ represents the abundance of $\delta^{18} \mathrm{O}$ of nitrate in mixed water sample, 
$\delta^{15} \mathrm{~N}_{i}$ represents the abundance of $\delta^{15} \mathrm{~N}$ in pollution source $i, \delta^{18} \mathrm{O}_{i}$ refers to the abundance of $\delta^{18} \mathrm{O}$ in pollution source $i$, and $f i$ is the total contribution ratios of three nitrate pollution sources.

Mass-balance mixing model is only suitable for calculating the contribution ratios of no more than three major nitrate pollution sources. Besides, this model fails to consider the incorporation of several substantial sources of uncertainty, such as spatial and temporal variability of nitrogen and oxygen isotopes of nitrate as well as the isotopic fractionation during nitrification [81]. Deutsch et al. [47], based on mass-balance mixing model, calculated the contribution ratios of irrigation water, groundwater, and precipitation to the nitrate of a river in Mecklenburg in Germany. The corresponding ratio was $86 \%, 11 \%$, and $4 \%$, respectively. Similarly, Voss et al. [82] quantified the contribution ratios of three pollution sources (sewage, precipitation, and soil) to nitrate in 12 tributaries of the Baltic Sea. Mass-balance model can be used in the rivers with simple sources of nitrate pollution. It can also be used in cases where the pollution sources are similar by treating them as one source. For instance, rural domestic sewage and manure are together regarded as rural pollution, and nitrification of soil nitrogen and chemical fertilizer are regarded as one agricultural non-point source pollution. Accordingly, targeted measures can be taken so as to prevent and control the pollution.

\subsection{SIAR Model}

SIAR (stable isotope analysis in R) mixing model, first established by Parnell et al. [50], is a logic prior distribution built based on Dirichlet distribution with Bayesian framework. It is used to estimate possible proportional source contribution, and then to determine the probability distribution for the proportional contribution of each source to the mixture. By defining the $j$ isotopes of $\mathrm{n}$ compounds from $\mathrm{k}$ sources, SIAR model can be expressed as

$$
\begin{gathered}
X_{i j}=\sum_{k=1}^{K} P_{k}\left(S_{j k}+c_{j k}\right)+\varepsilon_{i j}, \\
S_{j k} \sim N\left(\mu_{j k}, \omega_{j k}^{2}\right), \\
c_{j k} \sim N\left(\lambda_{j k}, \tau_{j k}^{2}\right), \\
\varepsilon_{i j} \sim N\left(0, \sigma_{j}^{2}\right),
\end{gathered}
$$

where $X_{i j}$ is the isotope value of $\mathrm{j}$ of mixture $i, P_{k}$ is the proportion of source $k, S_{j k}$ is the source value $k$ on isotope $j$ from source $i$ which obeys the normal distribution whose mean is $\mu$ and variance is $\omega$, and $c_{j k}$ is the fractionation factor of isotope $j$ from source $i$ which obeys the normal distribution whose mean is $\lambda$ and variance is $\tau$. $\varepsilon$ is the residual error which represents the variance of other compounds that cannot be quantified, and its mean and standard deviation are 0 under normal conditions.

SIAR model has been successfully applied in the source analysis of nitrate pollution as it takes into the identification of over three potential pollution sources and reduces the uncertainties of mass balance mixing model. With SIAR model, Xue et al. [66] successfully quantified the contribution ratios of five potential nitrate sources (precipitation, nitrate nitrogen fertilizer, ammonium nitrogen fertilizer, soil nitrogen, manure, and sewage). Zhang et al. [4], by using SIAR model, found that the nitrate of the irrigation water of Yellow River basin was mainly came from domestic sewage and manure (contribution ratio: 61-69\%) and chemical fertilizer (contribution ratio: 12-16\%). The nitrate pollution of rivers mostly caused by chemical fertilizer (contribution ratio: $21-58 \%$ ), soil $\mathrm{N}$ (contribution ratio: $16-35 \%$ ) and sewage and manure (contribution ratio: $4-49 \%$ ). In comparison to other models, the SIAR model has many advantages. For instance, it considers isotopic fractionation and is able to evaluate the contribution ratios of multiple (more than three) pollution sources. Nevertheless, any slight change in the isotopic composition of pollution source will lead to a significant change in the results of SIAR model [83]. In addition, the contribution ratios of different pollution sources calculated by SIAR model are ranges instead of determined values. 


\subsection{IsoSource Model}

IsoSource model, based on multisource linear mixing model (mass conservation model), is used to estimate the proportional contributions of $n+1$ sources to a mixture. After setting the source increment $(1-2 \%)$ and mass balance tolerance parameter $(0.01-0.05 \%)$, IsoSource model is able to calculate the contribution ratio of different pollution sources in water samples through iterative method. The possible combinations for the contribution rate of pollution source can be obtained by Equation (10)

$$
\mathrm{Q}=\frac{\left(\frac{100}{i}\right)+(s-1)}{s-1}=\frac{[(100 / i)+(s-1)] !}{(100 / i) !(s-1) !}
$$

where $Q$ is the quantity of combinations, $i$ is source increment, and $s$ is the number of pollution sources.

The IsoSource model can verify all the possible combinations for the potential contribution ratio of each source. When the difference between the weighted averages of $\delta^{15} \mathrm{~N}$ and $\delta^{18} \mathrm{O}$ of different sources and the compositions of $\delta^{15} \mathrm{~N}$ and $\delta^{18} \mathrm{O}$ of test water samples are smaller than $0.1 \%$, the solutions are considered possible. At present, the IsoSource model is mostly applied in the studies on atmosphere and plant water, and food web [84-86]. There are few studies that used IsoSource model to quantify the contribution ratio of pollution source to the nitrate of surface water. By using IsoSource model, Lu et al. [87] successfully calculated the variation ranges of chemical fertilizer (23-78\%), sewage $(6-58 \%)$, and soil organic nitrogen $(6-38 \%)$ in nitrate of surface water in the karst landform area of Guilin. Sheng et al. [88] illustrated the mechanism of nitrate source tracing through $\delta^{15} \mathrm{~N}$ and $\delta^{18} \mathrm{O}$. According to IsoSource model, a quantitative analysis on nitrate source at the mouth of Underground River was conducted. The contribution ratio of manure, soil organic nitrogen, $\mathrm{NH}_{4}{ }^{+}$in precipitation and fertilizer, and precipitation was $46.4 \%, 32.6 \%, 18.6 \%$, and $2.4 \%$, respectively. Different from SIAR model which needs programming, IsoSource model, characterized by simple and complete operation interface, is easy to use. Furthermore, it is able to calculate both the known contribution ratio and the potential contribution ratio of pollution source.

Despite the fact that SIAR mixing model and IsoSource model are established based on mass- balance mixing model, the uncertainties in the results of SIAR model should be further studied. Besides, the reliability of IsoSource model needs to be further verified since its applications in the source identification of nitrogen in surface water are rare. Furthermore, if it is possible to consider the precipitation, rivers, groundwater, and soil water as a whole system, a hydrological model and a geochemical reaction path model can be established. The study of water cycle and nitrogen cycle could provide powerful evidence for identify nitrate source in water environment.

\section{Conclusions and Suggestions}

When combining with hydrochemistry, hydrogeology, other isotopes, and mathematical models, the $\delta^{15} \mathrm{~N}$ and $\delta^{18} \mathrm{O}$ of nitrate are able to solve such problems as the partial overlapping of isotopic composition of various sources and isotopic composition reduced by isotopic fractionation. Thus, they are promising in confirming identification sources of nitrate pollution of surface water as well as in analyzing the transformation mechanisms. However, it should be pointed out that the following limitations lie in the current researches. (1) The isotopic compositions of nitrate from different sources have large spatial and temporal differences. The previous studies on isotope of different-form nitrogen are limited to scattered regions, and there is not any comprehensive study on the systematical changes of the nitrogen in global surface water or of the $\delta^{15} \mathrm{~N}$ and $\delta^{18} \mathrm{O}$ of nitrate. Therefore, a global isotopic database which could reflect the change of nitrogen and oxygen isotopes is missing. (2) Some researches only analyze nitrate sources by comparing the $\delta^{15} \mathrm{~N}$ and $\delta^{18} \mathrm{O}$ values of nitrate with the eigenvalues of $\delta^{15} \mathrm{~N}$ and $\delta^{18} \mathrm{O}$ of different sources and they fail to go deep into the isotope values of nitrate during migration and transformation. (3) The pretreatment methods for testing the compositions of nitrogen and oxygen isotopes are not cost-effective and have complex operating steps. It is quite important to make the method automatic, simple, and cost-effective. (4) The mechanisms of relevant 
processes are still unclear. For instance, there are only methods for the qualitative judgment of isotopic fractionation and there is lack of quantitative basis. That is, these methods can only ascertain whether isotopic fractionation occurs. They are unable to determine the extent of fractionation caused by biochemical reactions. As a result, the change degree of the compositions of original nitrogen and oxygen stable isotopes of nitrate as well as the influence of the change on research results cannot be analyzed thoroughly.

In order to overcome the limitations in the current researches and to make research progress, the following issues should be taken seriously. (1) The stable isotope values of nitrogen from different countries or regions are different owing to the various regional conditions. For the quick and accurate analysis on the nitrogen pollution source of the water bodies, the stable isotope values of nitrogen from different pollution sources should be gathered to establish a global and regional isotope database. (2) Nitrogen will go through multiple biochemical reactions when it transfers from the pollution source to water body, and these biochemical reactions are affected by such factors as land-use types, climate, and hydrogeological conditions. It is of great significance to study the influencing factors for identifying the pollution sources and tracing the migration and transformation ways of nitrogen. Besides, because of the complexity of river system, the geochemical investigation of isotope alone is not enough for revealing the geochemical cycle process of nitrate in rivers. Thus, nitrate sources of water can be identified more accurately if data involved in different fields are adopted. For example, the atmospheric precipitation, rivers, groundwater, and soil water are regarded as a whole when establishing a hydrological model, through which the hydrological cycle and nitrogen cycle can be better understand. (3) On the premise that the accuracy for measuring the isotope values is ensured, current methods should be optimized or new methods need to be explored. Thus, the isotope testing methods characterized by small sample size, high accuracy, automation, and low cost are the main focuses of the future researches on nitrogen pollution source. (4) The fractionation extent of the nitrogen and oxygen isotopes of nitrate of each process in nitrogen cycle should be quantified so as to increase the accuracy of quantitative identification. The data of the regions with similar hydrogeological conditions are processed and the denitrification rates under different conditions are determined in order to get the universal law. (5) The application of isotope in the quantitative calculation of contribution rates of nitrogen pollution sources is still the focus of future studies, thus the quantitative model should be further improved. Besides, the current mathematical models need to be optimized and verified to increase the accuracy and reliability of the results of quantitative analysis. Accordingly, targeted measures can be taken to control the major pollution sources according to the results.

Funding: This research was funded by the National Natural Science Foundation of China (grant no. 41601017 41601092 and 51308457), the Natural Science Foundation Research Project of Shaanxi Province (grant no. 2017JQ4001 and 13k798), and Program for Key Science and Technology Innovation Team in Shaanxi Province (grant no. 2014KCT-27).

Conflicts of Interest: The authors declare no conflict of interest.

\section{References}

1. Erisman, J.W.; Galloway, J.N.; Seitzinger, S.; Bleeker, A.; Dise, N.B.; Petrescu, A.M.R.; Leach, A.M.; de Vries, W. Consequences of human modification of the global nitrogen cycle. Philos. Trans. R. Soc. B-Boil. Sci. $2013,368$. [CrossRef] [PubMed]

2. He, B.; Kanae, S.; Oki, T.; Hirabayashi, Y.; Yamashiki, Y.; Takara, K. Assessment of global nitrogen pollution in rivers using an integrated biogeochemical modeling framework. Water Res. 2011, 45, 2573-2586. [CrossRef] [PubMed]

3. Haas, M.B.; Guse, B.; Fohrer, N. Assessing the impacts of Best Management Practices on nitrate pollution in an agricultural dominated lowland catchment considering environmental protection versus economic development. J. Environ. Manag. 2017, 196, 347-364. [CrossRef] 
4. Zhang, Y.; Shi, P.; Li, F.; Wei, A.; Song, J.; Ma, J. Quantification of nitrate sources and fates in rivers in an irrigated agricultural area using environmental isotopes and a Bayesian isotope mixing model. Chemosphere 2018, 208, 493-501. [CrossRef] [PubMed]

5. Zhang, Y.; Li, F.; Zhang, Q.; Li, J.; Liu, Q. Tracing nitrate pollution sources and transformation in surfaceand ground-waters using environmental isotopes. Sci. Total Environ. 2014, 490, 213-222. [CrossRef]

6. Bu, H.; Zhang, Y.; Meng, W.; Song, X. Effects of land-use patterns on in-stream nitrogen in a highly-polluted river basin in Northeast China. Sci. Total Environ. 2016, 553, 232-242. [CrossRef]

7. Kohl, D.H.; Shearer, G.B.; Commoner, B. Fertilizer nitrogen: Contribution to nitrate in surface water in a corn belt watershed. Science 1971, 174, 1331-1334. [CrossRef]

8. Stogbauer, A.; Strauss, H.; Arndt, J.; Marek, V.; Einsiedl, F.; van Geldern, R. Rivers of North-Rhine Westphalia revisited: Tracing changes in river chemistry. Appl. Geochem. 2008, 23, 3290-3304. [CrossRef]

9. Townsend-Small, A.; McCarthy, M.J.; Brandes, J.A.; Yang, L.; Zhang, L.; Gardner, W.S. Stable isotopic composition of nitrate in Lake Taihu, China, and major inflow rivers. Hydrobiologia 2007, 581, $135-140$. [CrossRef]

10. Savard, M.M.; Somers, G.; Smirnoff, A.; Paradis, D.; van Bochove, E.; Liao, S. Nitrate isotopes unveil distinct seasonal $\mathrm{N}$-sources and the critical role of crop residues in groundwater contamination. J. Hydrol. 2010, 381, 134-141. [CrossRef]

11. Kendall, C. Tracing Nitrogen Sources and Cycling in Catchments. In Isotope Tracers in Catchment Hydrology, 1st ed.; Kendall, C., McDonnell, J.J., Eds.; Elsevier Science: Amsterdam, The Netherlands, 1998; pp. 519-576.

12. Xue, D.; Botte, J.; De Baets, B.; Accoe, F.; Nestler, A.; Taylor, P.; Van Cleemput, O.; Berglund, M.; Boeckx, P. Present limitations and future prospects of stable isotope methods for nitrate source identification in surfaceand groundwater. Water Res. 2009, 43, 1159-1170. [CrossRef] [PubMed]

13. Finlay, J.C.; Sterner, R.W.; Kumar, S. Isotopic evidence for inlake production of accumulating nitrate in Lake Superior. Ecol. Appl. 2009, 17, 2323-2332. [CrossRef]

14. Jia, G.D.; Chen, F.J. Monthly variations in nitrogen isotopes of ammonium and nitrate in wet deposition at Guangzhou, south China. Atmos. Environ. 2010, 44, 2309-2315. [CrossRef]

15. Jiang, Y.J.; Wu, Y.X.; Yuan, D.X. Human impacts on karst groundwater contamination deduced by coupled nitrogen with strontium isotopes in the Nandong underground river system in Yunan, China. Environ. Sci. Technol. 2009, 43, 7676-7683. [CrossRef] [PubMed]

16. Fang, Y.T.; Koba, K.; Wang, X.M.; Wen, D.Z.; Li, J.; Takebayashi, Y.; Liu, X.Y.; Yoh, M. Anthropogenic imprints on nitrogen and oxygen isotopic composition of precipitation nitrate in a nitrogen-polluted city in southern China. Atmos. Chem. Phys. 2011, 11, 1313-1325. [CrossRef]

17. Felix, J.D.; Elliott, E.M.; Avery, G.B.; Kieber, R.J.; Mead, R.N.; Willey, J.D.; Mullaugh, K.M. Isotopic composition of nitrate in sequential Hurricane Irene precipitation samples: Implications for changing NOx sources. Atmos. Environ. 2015, 106, 191-195. [CrossRef]

18. Xing, M.; Liu, W. Using dual isotopes to identify sources and transformations of nitrogen in water catchments with different land uses, Loess Plateau of China. Environ. Sci. Pollut. Res. 2016, 23, 388-401. [CrossRef] [PubMed]

19. Li, S.L.; Liu, C.Q.; Li, J.; Liu, X.; Chetelat, B.; Wang, B.; Wang, F. Assessment of the sources of nitrate in the Changjiang River, China using a nitrogen and oxygen isotopic approach. Environ. Sci. Technol. 2010, 44, 1573-1578. [CrossRef]

20. Michalski, G.; Kolanowski, M.; Riha, K.M. Oxygen and nitrogen isotopic composition of nitrate in commercial fertilizers, nitric acid, and reagent salts. Isot. Environ. Health Stud. 2015, 51, 382-391. [CrossRef] [PubMed]

21. Granger, J.; Wankel, S.D. Isotopic overprinting of nitrification on denitrification as a ubiquitous and unifying feature of environmental nitrogen cycling. Proc. Natl. Acad. Sci. USA 2016, 113, E6391-E6400. [CrossRef] [PubMed]

22. Kellman, L.M. A study of tile drain nitrate- $\delta^{15} \mathrm{~N}$ values as a tool for assessing nitrate sources in an agricultural region. Nutr. Cycl. Agroecosyst. 2005, 71, 131-137. [CrossRef]

23. Kendall, C.; Elliott, E.M.; Wankel, S.D. Tracing anthropogenic inputs of nitrogen to ecosystems. Stable Isot. Ecol. Environ. Sci. 2007, 2, 375-449. [CrossRef]

24. Rivett, M.O.; Buss, S.R.; Morgan, P.; Smith, J.W.N.; Bemment, C.D. Nitrate attenuation in groundwater: A review of biogeochemical controlling processes. Water Res. 2008, 42, 4215-4232. [CrossRef] [PubMed] 
25. Sebilo, M.; Billen, G.; Grably, M.; Mariotti, A. Isotopic composition of nitrate-nitrogen as a marker of riparian and benthic denitrification at the scale of the whole Seine River system. Biogeochemistry 2003, 63, 35-51. [CrossRef]

26. Wenk, C.B.; Zopfi, J.; Blees, J.; Veronesi, M.; Niemann, H.; Lehmann, M.F. Community N and O isotope fractionation by sulfide-dependent denitrification and anammox in a stratified lacustrine water column. Geochim. Cosmochim. Acta 2014, 125, 551-563. [CrossRef]

27. Kaushal, S.S.; Groffman, P.M.; Band, L.E.; Elliott, E.M.; Shields, C.A.; Kendall, C. Tracking Nonpoint Source Nitrogen Pollution in Human-Impacted Watersheds. Environ. Sci. Technol. 2011, 45, 8225-8232. [CrossRef]

28. Burns, D.A.; Boyer, E.W.; Elliott, E.M.; Kendall, C. Sources and Transformations of Nitrate from Streams Draining Varying Land Uses: Evidence from Dual Isotope Analysis. J. Environ. Qual. 2009, 38, 1149-1159. [CrossRef]

29. Osaka, K.i.; Ohte, N.; Koba, K.; Yoshimizu, C.; Katsuyama, M.; Tani, M.; Tayasu, I.; Nagata, T. Hydrological influences on spatiotemporal variations of $\delta^{15} \mathrm{~N}$ and $\delta^{18} \mathrm{O}$ of nitrate in a forested headwater catchment in central Japan: Denitrification plays a critical role in groundwater. J. Geophys. Res. Biogeosci. $2010,115$. [CrossRef]

30. Robinson, D. $\delta^{15} \mathrm{~N}$ as an integrator of the nitrogen cycle. Trends Ecol. Evol. 2001, 16, 153-162. [CrossRef]

31. Granger, J.; Sigman, D.M.; Needoba, J.A.; Harrison, P.J. Coupled nitrogen and oxygen isotope fractionation of nitrate during assimilation by cultures of marine phytoplankton. Limnol. Oceanogr. 2004, 49, 1763-1773. [CrossRef]

32. Nestler, A.; Berglund, M.; Accoe, F.; Duta, S.; Xue, D.; Boeckx, P.; Taylor, P. Isotopes for improved management of nitrate pollution in aqueous resources: Review of surface water field studies. Environ. Sci. Pollut. Res. 2011, 18, 519-533. [CrossRef]

33. Seitzinger, P.S.; Styles, R.V.; Boyer, E.; Boyer, E.W.; Alexander, R.B.; Billen, G.; Howarth, R.W.; Mayer, B.; Breemen, N.V. Nitrogen retention in rivers: Model development and application to watersheds in the northeastern USA. Biogeochemistry 2002, 57-58, 199-237. [CrossRef]

34. Deutsch, B.; Voss, M.; Fischer, H. Nitrogen transformation processes in the Elbe River: Distinguishing between assimilation and denitrification by means of stable isotope ratios in nitrate. Aquat. Sci. 2009, 71, 228-237. [CrossRef]

35. Silva, S.R.; Kendall, C.; Wilkison, D.H.; Ziegler, A.C.; Chang, C.C.Y.; Avanzino, R.J. A new method for collection of nitrate from fresh water and the analysis of nitrogen and oxygen isotope ratios. J. Hydrol. 2000, 228, 22-36. [CrossRef]

36. Garten, C.T. Nitrogen isotope composition of ammonium and nitrate in bulk precipitation and forest throughfall. Int. J. Environ. Anal. Chem. 1992, 47, 32-45. [CrossRef]

37. Tu, Y.; Fang, Y.; Liu, D.; Pan, Y. Modifications to the azide method for nitrate isotope analysis. Rapid Commun. Mass Spectrom. 2016, 30, 1213-1222. [CrossRef] [PubMed]

38. Li, W.B.; Song, Y.B.; Xu, H.K.; Chen, L.Y.; Dai, W.H.; Dong, M. Ion-exchange method in the collection of nitrate from freshwater ecosystems for nitrogen and oxygen isotope analysis: A review. Environ. Sci. Pollut. Res. 2015, 22, 9575-9588. [CrossRef] [PubMed]

39. Sigman, D.; Casciotti, K.; Andreani, M.; Barford, C.; Galanter, M.; Böhlke, J. A bacterial method for the nitrogen isotopic analysis of nitrate in seawater and freshwater. Anal. Chem. 2001, 73, 4145-4153. [CrossRef]

40. Casciotti, K.L.; Sigman, D.M.; Hastings, M.G.; Bohlke, J.K.; Hilkert, A. Measurement of the oxygen isotopic composition of nitrate in seawater and freshwater using the denitrifier method. Anal. Chem. 2002, 74, 4905-4912. [CrossRef]

41. Coplen, T.B.; Qi, H.P.; Revesz, K.; Casciotti, K.; Hannon, J.E. Determination of the $\delta^{15} N$ and $\delta^{18} \mathrm{O}$ of Nitrate in Water; RSIL Lab Code 2900; U.S. Geological Survey: Reston, VA, USA, 2007. [CrossRef]

42. Granger, J.; Sigman, D.M.; Prokopenko, M.G.; Lehmann, M.F.; Tortell, P.D. A method for nitrite removal in nitrate $\mathrm{N}$ and $\mathrm{O}$ isotope analyses. Limnol. Oceanogr. Methods 2006, 4, 205-212. [CrossRef]

43. Casciotti, K.L.; Boehlke, J.K.; McIlvin, M.R.; Mroczkowski, S.J.; Hannon, J.E. Oxygen isotopes in nitrite: Analysis, calibration, and equilibration. Anal. Chem. 2007, 79, 2427-2436. [CrossRef] [PubMed]

44. Zhu, J.; Yu, L.; Bakken, L.R.; Morkved, P.T.; Mulder, J.; Dorsch, P. Controlled induction of denitrification in Pseudomonas aureofaciens: A simplified denitrifier method for dual isotope analysis in $\mathrm{NO}_{3}$. Sci. Total Environ. 2018, 633, 1370-1378. [CrossRef] [PubMed] 
45. Mcllvin, M.R.; Altabet, M.A. Chemical conversion of nitrate and nitrite to nitrous oxide for nitrogen and oxygen isotopic analysis in freshwater and seawater. Anal. Chem. 2005, 77, 5589-5595. [CrossRef] [PubMed]

46. Wassenaar, L.I.; Douence, C.; Altabet, M.A.; Aggarwal, P.K. $N$ and O isotope $\left(\delta^{15} \mathrm{~N}^{\alpha}, \delta^{15} \mathrm{~N}^{\beta}, \delta^{18} \mathrm{O}, \delta^{17} \mathrm{O}\right)$ analyses of dissolved $\mathrm{NO}_{3}{ }^{-}$and $\mathrm{NO}_{2}{ }^{-}$by the Cd-azide reduction method and $\mathrm{N}_{2} \mathrm{O}$ laser spectrometry. Rapid Commun. Mass Spectrom. 2018, 32, 184-194. [CrossRef]

47. Deutsch, B.; Mewes, M.; Liskow, I.; Voss, M. Quantification of diffuse nitrate inputs into a small river system using stable isotopes of oxygen and nitrogen in nitrate. Org. Geochem. 2006, 37, 1333-1342. [CrossRef]

48. Ding, J.; Xi, B.; Gao, R.; He, L.; Liu, H.; Dai, X.; Yu, Y. Identifying diffused nitrate sources in a stream in an agricultural field using a dual isotopic approach. Sci. Total Environ. 2014, 484, 10-18. [CrossRef] [PubMed]

49. Peña-Haro, S.; Llopis-Albert, C.; Pulido-Velazquez, M.; Pulido-Velazquez, D. Fertilizer standards for controlling groundwater nitrate pollution from agriculture: El Salobral-Los Llanos case study, Spain. J. Hydrol. 2010, 392, 174-187. [CrossRef]

50. Parnell, A.C.; Inger, R.; Bearhop, S.; Jackson, A.L. Source partitioning using stable isotopes: Coping with too much variation. PLoS ONE 2010, 5, e9672. [CrossRef]

51. Barnes, R.T.; Raymond, P.A.; Casciotti, K.L. Dual isotope analyses indicate efficient processing of atmospheric nitrate by forested watersheds in the northeastern US. Biogeochemistry 2008, 90, 15-27. [CrossRef]

52. Hales, H.C.; Ross, D.S.; Lini, A. Isotopic signature of nitrate in two contrasting watersheds of Brush Brook, Vermont, USA. Biogeochemistry 2007, 84, 51-66. [CrossRef]

53. Buda, A.R.; DeWalle, D.R. Dynamics of stream nitrate sources and flow pathways during stormflows on urban, forest and agricultural watersheds in central Pennsylvania, USA. Hydrol. Process. 2009, 23, 3292-3305. [CrossRef]

54. Chen, Z.X.; Liu, G.; Liu, W.G.; Lam, M.H.W.; Liu, G.J.; Yin, X.B. Identification of nitrate sources in Taihu Lake and its major inflow rivers in China, using ${ }^{15} \mathrm{~N}_{-} \mathrm{NO}_{3}{ }^{-}$and $\delta^{18} \mathrm{O}-\mathrm{NO}_{3}{ }^{-}$values. Water Sci. Technol. 2012, 66, 536-542. [CrossRef] [PubMed]

55. Lee, K.S.; Bong, Y.S.; Lee, D.; Kim, Y.; Kim, K. Tracing the sources of nitrate in the Han River watershed in Korea, using $\delta^{15} \mathrm{~N}^{-N}{ }_{3}{ }^{-}$and $\delta^{18} \mathrm{O}-\mathrm{NO}_{3}{ }^{-}$values. Sci. Total Environ. 2008, 395, 117-124. [CrossRef] [PubMed]

56. Ren, Y.; Xu, Z.; Zhang, X.; Wang, X.; Sun, X.; Ballantine, D.J.; Wang, S. Nitrogen pollution and source identification of urban ecosystem surface water in Beijing. Front. Environ. Sci. Eng. 2014, 8, 106-116. [CrossRef]

57. Popescu, R.; Mimmo, T.; Dinca, O.R.; Capici, C.; Costinel, D.; Sandru, C.; Ionete, R.E.; Stefanescu, I.; Axente, D. Using stable isotopes in tracing contaminant sources in an industrial area: A case study on the hydrological basin of the Olt River, Romania. Sci. Total Environ. 2015, 533, 17-23. [CrossRef] [PubMed]

58. Archana, A.; Thibodeau, B.; Geeraert, N.; Xu, M.N.; Kao, S.-J.; Baker, D.M. Nitrogen sources and cycling revealed by dual isotopes of nitrate in a complex urbanized environment. Water Res. 2018, 142, 459-470. [CrossRef] [PubMed]

59. Battaglin, W.A.; Kendall, C.; Chang, C.C.Y.; Silva, S.R.; Campbell, D.H. Chemical and isotopic evidence of nitrogen transformation in the Mississippi River, 1997-1998. Hydrol. Process. 2001, 15, 1285-1300. [CrossRef]

60. Liu, T.; Wang, F.; Michalski, G.; Xia, X.; Liu, S. Using ${ }^{15} \mathrm{~N},{ }^{17} \mathrm{O}$, and ${ }^{18} \mathrm{O}$ to determine nitrate sources in the Yellow River, China. Environ. Sci. Technol. 2013, 47, 13412-13421. [CrossRef] [PubMed]

61. Yue, F.J.; Liu, C.Q.; Li, S.L.; Zhao, Z.Q.; Liu, X.L.; Ding, H.; Liu, B.J.; Zhong, J. Analysis of $\delta^{15} \mathrm{~N}$ and $\delta^{18} \mathrm{O}$ to identify nitrate sources and transformations in Songhua River, Northeast China. J. Hydrol. 2014, 519, 329-339. [CrossRef]

62. Panno, S.V.; Kelly, W.R.; Hackley, K.C.; Hwang, H.H.; Martinsek, A.T. Sources and fate of nitrate in the Illinois River Basin, Illinois. J. Hydrol. 2008, 359, 174-188. [CrossRef]

63. Rock, L.; Mayer, B. Isotopic assessment of sources of surface water nitrate within the Oldman River basin, Southern Alberta, Canada. In Biogeochemical Investigations of Terrestrial, Freshwater, and Wetland Ecosystems across the Globe, 2nd ed.; Wieder, R.K., Novák, M., Vile, M.A., Eds.; Springer: Dordrecht, The Netherlands, 2004; pp. 545-562.

64. Soto, D.X.; Koehler, G.; Wassenaar, L.I.; Hobson, K.A. Spatio-temporal variation of nitrate sources to Lake Winnipeg using $\mathrm{N}$ and $\mathrm{O}$ isotope $\left(\delta^{15} \mathrm{~N}, \delta^{18} \mathrm{O}\right)$ analyses. Sci. Total Environ. 2019, 647, 486-493. [CrossRef] [PubMed] 
65. Urresti-Estala, B.; Vadillo-Perez, I.; Jimenez-Gavilan, P.; Soler, A.; Sanchez-Garcia, D.; Carrasco-Cantos, F. Application of stable isotopes $\left(\delta^{34} \mathrm{~S}_{-} \mathrm{SO}_{4}, \delta^{18} \mathrm{O}-\mathrm{SO}_{4}, \delta^{15} \mathrm{~N}-\mathrm{NO}_{3}, \delta^{18} \mathrm{O}-\mathrm{NO}_{3}\right)$ to determine natural background and contamination sources in the Guadalhorce River Basin (southern Spain). Sci. Total Environ. 2015, 506, 46-57. [CrossRef] [PubMed]

66. Xue, D.; De Baets, B.; Van Cleemput, O.; Hennessy, C.; Berglund, M.; Boeckx, P. Classification of nitrate polluting activities through clustering of isotope mixing model outputs. J. Environ. Qual. 2013, 42, 1486-1497. [CrossRef] [PubMed]

67. Chen, F.; Jia, G.; Chen, J. Nitrate sources and watershed denitrification inferred from nitrate dual isotopes in the Beijiang River, south China. Biogeochemistry 2009, 94, 163-174. [CrossRef]

68. Mayer, B.; Boyer, E.W.; Goodale, C.; Jaworski, N.A.; Van Breemen, N.; Howarth, R.W.; Seitzinger, S.; Billen, G.; Lajtha, L.J.; Nosal, M.; et al. Sources of nitrate in rivers draining sixteen watersheds in the northeastern US: Isotopic constraints. Biogeochemistry 2002, 57, 171-197. [CrossRef]

69. Showers, W.J.; Genna, B.; McDade, T.; Bolich, R.; Fountain, J.C. Nitrate contamination in groundwater on an urbanized dairy farm. Environ. Sci. Technol. 2008, 42, 4683-4688. [CrossRef] [PubMed]

70. Marfia, A.M.; Krishnamurthy, R.V.; Atekwana, E.A.; Panton, W.F. Isotopic and geochemical evolution of ground and surface waters in a karst dominated geological setting: A case study from Belize, Central America. Appl. Geochem. 2004, 19, 937-946. [CrossRef]

71. Li, C.; Jiang, Y.; Guo, X.; Cao, Y.; Ji, H. Multi-isotope $\left({ }^{15} \mathrm{~N},{ }^{18} \mathrm{O}\right.$ and $\left.{ }^{13} \mathrm{C}\right)$ indicators of sources and fate of nitrate in the upper stream of Chaobai River, Beijing, China. Environ. Sci. Process. Impacts 2014, 16, $2644-2655$. [CrossRef]

72. Widory, D.; Petelet-Giraud, E.; Brenot, A.; Bronders, J.; Tirez, K.; Boeckx, P. Improving the management of nitrate pollution in water by the use of isotope monitoring: The $\delta^{15} \mathrm{~N}, \delta^{18} \mathrm{O}$ and $\delta^{11} \mathrm{~B}$ triptych. Isot. Environ. Health Stud. 2013, 49, 29-47. [CrossRef]

73. Michalski, G.; Scott, Z.; Kabiling, M.; Thiemens, M.H. First measurements and modeling of $\Delta^{17} \mathrm{O}$ in atmospheric nitrate. Geophys. Res. Lett. 2003, 30, 1870. [CrossRef]

74. Tsunogai, U.; Daita, S.; Komatsu, D.D.; Nakagawa, F.; Tanaka, A. Quantifying nitrate dynamics in an oligotrophic lake using $\Delta^{17} \mathrm{O}$. Biogeosciences 2011, 8, 687-702. [CrossRef]

75. Saccon, P.; Leis, A.; Marca, A.; Kaiser, J.; Campisi, L.; Böttcher, M.E.; Savarino, J.; Escher, P.; Eisenhauer, A.; Erbland, J. Multi-isotope approach for the identification and characterisation of nitrate pollution sources in the Marano lagoon (Italy) and parts of its catchment area. Appl. Geochem. 2013, 34, 75-89. [CrossRef]

76. Wollheim, W.M.; Mulukutla, G.K.; Cook, C.; Carey, R.O. Aquatic nitrate retention at river network scales across flow conditions determined using nested in situ sensors. Water Resour. Res. 2017, 53, 9740-9756. [CrossRef]

77. Xue, D.M.; Pang, F.M.; Meng, F.Q.; Wang, Z.L.; Wu, W.L. Decision-tree-model identification of nitrate pollution activities in groundwater: A combination of a dual isotope approach and chemical ions. J. Contam. Hydrol. 2015, 180, 25-33. [CrossRef] [PubMed]

78. Phillips, D.L.; Gregg, J.W. Uncertainty in source partitioning using stable isotopes. Oecologia 2001, 127, 171-179. [CrossRef] [PubMed]

79. Serio, F.; Miglietta, P.P.; Lamastra, L.; Ficocelli, S.; Intini, F.; De Leo, F.; De Donno, A. Groundwater nitrate contamination and agricultural land use: A grey water footprint perspective in Southern Apulia Region (Italy). Sci. Total Environ. 2018, 645, 1425-1431. [CrossRef] [PubMed]

80. Phillips, D.L.; Koch, P.L. Incorporating concentration dependence in stable isotope mixing models. Oecologia 2002, 130, 114-125. [CrossRef]

81. Moore, J.W.; Semmens, B.X. Incorporating uncertainty and prior information into stable isotope mixing models. Ecol. Lett. 2008, 11, 470-480. [CrossRef]

82. Voss, M.; Deutsch, B.; Elmgren, R.; Humborg, C.; Kuuppo, P.; Pastuszak, M.; Rolff, C.; Schulte, U. Source identification of nitrate by means of isotopic tracers in the Baltic Sea catchments. Biogeosciences 2006, 3, 663-676. [CrossRef]

83. Xue, D.; De Baets, B.; Van Cleemput, O.; Hennessy, C.; Berglund, M.; Boeckx, P. Use of a Bayesian isotope mixing model to estimate proportional contributions of multiple nitrate sources in surface water. Environ. Pollut. 2012, 161, 43-49. [CrossRef]

84. Zeng, Y.; Tian, S.; Pan, Y. Revealing the Sources of Atmospheric Ammonia: A Review. Curr. Pollut. Rep. 2018, 4, 189-197. [CrossRef] 
85. Derrien, M.; Kim, M.S.; Ock, G.; Hong, S.; Cho, J.; Shin, K.H.; Hur, J. Estimation of different source contributions to sediment organic matter in an agricultural-forested watershed using end member mixing analyses based on stable isotope ratios and fluorescence spectroscopy. Sci. Total Environ. 2018, 618, 569-578. [CrossRef] [PubMed]

86. Herwig, B.R.; Wahl, D.H.; Dettmers, J.M.; Soluk, D.A. Spatial and temporal patterns in the food web structure of a large floodplain river assessed using stable isotopes. Can. J. Fish. Aquat. Sci. 2007, 64, 495-508. [CrossRef]

87. Lu, L.; Li, W.L.; Pei, J.G.; Wang, Z. A quantitative study of the sources of nitrate of Zhaidi Underground River in Guilin based on IsoSource. Acta Geosci. Sin. 2014, 35, 248-254. [CrossRef]

88. Sheng, T.; Yang, P.H.; Xie, G.W.; Hong, A.H.; Cao, C.; Xie, S.Y.; Shi, W.Y. Nitrate-nitrogen pollution sources of and underground river in Karst agricultural area using ${ }^{15} \mathrm{~N}$ and ${ }^{18} \mathrm{O}$ isotope technique. Environ. Sci. 2018, 39, 4547-4555. [CrossRef]

(C) 2018 by the authors. Licensee MDPI, Basel, Switzerland. This article is an open access article distributed under the terms and conditions of the Creative Commons Attribution (CC BY) license (http://creativecommons.org/licenses/by/4.0/). 